\title{
Сапач Т.И.
}

\section{Возмещение убытков в качестве санкции за злоупотребление правом}

ФГБОУ ВО «Смоленский государственный университет»

(Россия, Смоленск)

doi: $10.18411 / \mathrm{j}-10-2019-92$

idsp: ljournal-10-2019-92

\section{Аннотация}

В статье рассматриваются вопросы, связанные с понятием «злоупотребление правом». В представленной статье автор уделяет внимание возможности взыскать убытки, причиненные злоупотреблением правом, и восстановить свое материальное положение, имевшее место до факта злоупотребления правом.

Ключевые слова: убытки, возмещение убытков, злоупотребление правом, шикана, гражданское право

\section{Abstract}

The article discusses issues related to the concept of "abuse of rights". In the presented article, the author pays attention to the opportunity to recover losses incurred by abuse of rights, and thus restore his financial situation, which took place before the fact of abuse of rights.

Keywords: abuse of rights, damages, material losses, prohibition of chicane, civil law

Представить современное общество без права, пронизывающего все уровни общественной жизни, весьма проблематично. Можно со стопроцентной уверенностью говорить о том, что право является одним из «трех китов», на которых стоит современный мир.

Несмотря на то, что право, как отмечал профессор Т.Н. Радько, имеет своим социальным назначением закрепление и стабилизацию наиболее важных, необходимых в обществе отношений, искоренение определенных негативных явлений из жизни общества, создание условий для благоприятного развития новых, более прогрессивных видов общественных отношений, случаи злоупотреблений правом имеют место быть.

Злоупотребление правом не является каким-то новым явлением для юриспруденции. Упоминания о злоупотребления правом можно найти еще у юристов Древнего мира. Примером могут служить Законы Хаммурапи, Дигесты Юстиниана и Институции Гая.

В СССР законодательно положения о злоупотреблении правом закреплены не были, но это не мешало рассматривать проблематику злоупотребления правом в своих трудах советским цивилистам. В этот период данной проблеме уделяли внимание М.M. Агарков, М.И. Бару, В.П. Грибанов, О.С. Иоффе и другие.

Современное гражданское законодательство России также не обходит стороной понятие «злоупотребление правом». Статья 10 Гражданского кодекса Российской Федерации (далее - ГК РФ) закрепляет следующие формы злоупотребления правом:

- осуществление гражданских прав исключительно с намерением причинить вред другому лицу (шикана);

- действия в обход закона с противоправной целью;

- $\quad$ иное заведомо недобросовестное осуществление гражданских прав.

Как мы можем видеть, наличие в ГК РФ статьи 10, говорит о прямом запрете злоупотребления правом. Кроме того, из анализа статьи следует, что законодатель оставляет открытым перечень деяний, относящихся к злоупотреблению правом. На наш взгляд такая позиция законодателя является верной. Мы считаем, что дальнейшее 
законодательное уточнение понятия злоупотребление правом может привести к ограничению диспозитивности гражданского законодательства.

Несмотря на существование статьи 10 ГК РФ, легального определения «злоупотребления правом» в российском гражданском праве нет. Сложность, а одновременно и интерес, вызывает также и тот факт, что в теории гражданского права отсутствует однозначное мнение относительно того, что собой представляет «злоупотребление правом».

Для того чтобы говорить о наличии злоупотребления правом необходимо наличие непосредственно права, которым злоупотребляют. Соответственно, лицо которое понесло убытки вследствие злоупотребления правом, должно доказать, что имело место злоупотребление правом со стороны причинителя вреда.

Уже в римском праве мы можем увидеть свидетельства того, что возмещение убытков выступает санкцией и универсальной мерой ответственности.

В научной литературе можно найти множество классификаций убытков, но наиболее важной является та, что вытекает из содержания статьи 15 ГК РФ. Если ранее мы отмечали, что пункт 1 статьи 10 ГК РФ не дает нам исчерпывающего перечня деяний, которые можно отнести к злоупотреблению правом, то с понятием «убытки» все обстоит иначе.

Пункт 2 статьи 15 ГК РФ дает нам исчерпывающий, закрытый перечень того, что согласно российскому законодательству мы можем считать убытками. Согласно пункту 2 статьи 15 ГК РФ убытки делятся на два вида: реальный ущерб и упущенная выгода. Такое деление убытков сегодня признается большинством стран.

В ходе реформ, проводимых российскими законодателями, в статье 10 ГК РФ появилось прямое указание на возможность взыскать убытки, понесенные в связи со злоупотреблением правом.

Статья 15 ГК РФ предусматривает принцип полного возмещения убытков. Согласно названной статье для применения санкции в виде возмещения убытков необходимо доказать:

1) наступление вреда;

2) противоправность деяния;

3) вину причинителя вреда;

4) причинно-следственную связь между действиями причинителя вреда и наступившими неблагоприятными для пострадавшего лица последствиями.

Таким образом, мы видим, что пострадавшее лицо может рассчитывать на благоприятный для себя исход рассмотрения гражданского дела только при наличии и доказанности всех указанных выше элементов.

Несмотря на практическую значимость возможности взыскать убытки с лица злоупотребившим правом, пункт 4 статьи 10 ГК РФ применяется судами относительно редко. Проанализировав опубликованные решения судов общей юрисдикции Смоленской области за 2015-2019 гг., мы нашли только одно решение суда, в котором был применен пункт 4 статьи 10 ГК РФ.

На наш взгляд, суды общей юрисдикции должны брать пример с арбитражных судов, которые не боятся ссылаться на статью 10 ГК РФ в своих решениях.

В российском гражданском законодательстве много внимания уделяется способам защиты и средствам восстановления имущественного положения пострадавшего. Одной из мер ответственности, направленной на восстановление права, является возмещение убытков. Цель этой меры, обладающей признаками универсальности и всеобщности действия - максимально полно восстановить все имущественные потери, однако, в отечественной юридической среде бытует мнение о 
том, что исчисление и доказывание убытков в суде представляет серьезную процессуальную сложность.

Данная санкция является не только охранительной, но и носит восстановительный характер для пострадавшего участника гражданско-правовых отношений.

Можно долго спорить является ли злоупотребление правом правонарушением, однако абсолютно точно можно сказать, что в силу пункта 1 статьи 10 ГК РФ злоупотребление правом запрещено законом. При рассмотрении дел о взыскании убытков в связи с злоупотреблением правом арбитражные суды исходят из того, что реализация такого способа защиты нарушенного права, как возмещение убытков возможна при наличии общих условий гражданско-правовой ответственности: совершения ответчиком противоправного действия (бездействия), возникновения у потерпевшего убытков и их размер, причинно-следственной связи между действиями ответчика и наступившими последствиями.

На наш взгляд, возможность возмещение убытков является не просто серьезной санкцией для виновного лица, а что не менее важно возможностью пострадавшего лица восстановить то материальное положение, которое существовало до нарушения его прав. В реальности, где во главе угла стоит материальная выгода, возмещение убытков является серьезным подспорьем.

\section{$* * *$}

1. Братусь С.Н. О пределах осуществления гражданских прав//Правоведение. 1967. №3. - 183 с.

2. Волков А.В. «Возмещение убытков по гражданскому праву России» Волгоград: Государственное учреждение «Издатель», 2000. С. 2-3

3. Гражданский кодекс Российской Федерации: Часть первая - четвертая: [Принят Гос. Думой 23 апреля 1994 года, с изменениями и дополнениями по состоянию на 10 апреля 2009 г.] // Собрание законодательства РФ. - 1994. - № 22. Ст. 2457

4. Грибанов В.П. Осуществление и защита гражданских прав. Изд. 2-е, стереотип. - М.: «Статут», 2001. $-411 \mathrm{c}$.

5. Грибанов В.П. Принципы осуществления гражданских прав // Вестник МГУ. Серия XII «Право». 1966 № 3.

6. Конституция (Основной Закон) Российской Федерации: [Принята общенародным голосованием в 1993г.] // Российская газета. - 1993. - № 248.

7. Кузнецова О.А. Применение мер гражданско-правовой ответственности // Вестник Пермского университета. Юридические науки. 2012. № 4 (18). С. 97-103.

8. Радько Т.Н. Теория функций права. - М. : Проспект, 2014. - 269 с.

9. Учебник «Римское частное право» (под ред. И. Б. Новицкого, И. С. Перетерского) Юристъ, 2004. 337 c.

\section{Валуйсков Н.В., Сасина К.С. \\ Проблемы правового регулирования ограничения и обременения обязательственных прав \\ ИСОиП (филиал) ДГТУ в г. Шахты (Россия, Шахты)}

doi: 10.18411/lj-10-2019-93

idsp: ljournal-10-2019-93

Аннотация

В данной статье рассмотрены законодательные проблемы ограничения и обременения обязательственных прав.

Ключевые слова: ограничения, обременения, проблемы, регулирование, обязательственное, право. 